\title{
THE PARALLEL ECONOMY IN INDIA: CAUSES, IMPACTS AND GOVERNMENT INITIATIVES
}

\author{
Sukanta Sarkar*
}

\begin{abstract}
The study has made an attempt to assess the overall profile of parallel economy in India, particularly in terms of causes, impacts and government initiatives. The results indicate that parallel economy has been expanding very rapidly in India as well as in developing countries. It is evident from the study that government of India already introduced various commissions for estimating black economy but estimation reports are not same. Indian government is more concerned about the prevalence of the parallel economy and various commissions are formed for controlling it but results are not so impressive. Thus, the paper suggests that recommendations of the commissions or laws should be implemented correctly for reducing bad effects of black economy.
\end{abstract}

Key words: black money, inflation, privatization, real estate, India

"In popular parlance, the unofficial economy goes by the name of black money and the official, of white money. Black and white are also variously substituted by number two and number one, un-accounted and accounted, unreported and reported, unrecorded and recorded and so on". -Prof. J.C. Sandesara

\section{INTRODUCTION}

Economy consists of economic system of a country or other area, the labor, capital and land resources, and the economic agents that socially participate in the production, exchange, distribution, and consumption of goods and services of that area. All kind of professions, occupations, economic agents or economic activities, contribute to the economy. Consumption, saving and investment are core components in the economy and determine market equilibrium. An informal economy is economic activity that is neither taxed nor monitored by a government, contrasted with a formal economy. The informal economy is thus not included in that government's Gross National Product (GNP). Informal economic activity is a dynamic process which includes many aspects of economic and social theory including exchange, regulation, and enforcement.

Parallel economy means functioning of an unsanctioned sector in the economy whose objectives run parallel and in contradiction with the objectives of official or sanctioned

\footnotetext{
* Mr. Sarkar is Lecturer of economics, Department of Management, ICFAI University Tripura, Agartala, Email: skntsarkar5@gmail.com
} 
or legitimate sector in the same economy (Rajaram, 2006, 577). This is variously referred to as 'unaccounted economy', 'illegal economy', 'subterranean economy', or 'unsanctioned economy'. According to the D.K.Rangnekar (as cited by Datta \& Sundharam, 2004, 376), "If the 'Parallel economy' poses a serious threat to stability and growth of the official economy, surely it stems from the fact that the magnitude of 'black-money' is large and rigged deals are growing in volume and complexity at an alarming rate. Apart from the wide ramifications of the 'parallel economy', one might also be alive to the fact that 'black incomes' are accentuating the inequalities in income and wealth and breeding a new class of 'black' rich in a society which is already harshly stratified."

Illegal economy is tax-evaded economy. It is possible to convert illegal economy or black money into white money and vice versa. For example, when a person manages to get the receipt from the shopkeeper by paying the sales-tax for a commodity but does not purchase it actually, he generates black money as reimbursement is made to him against the receipt. The money not actually paid is the black money in such a case. In such case, the shopkeeper sells the same commodity to another person without giving him any receipt for it. On the other hand, if a person purchases something (say, a scooter, or a VCR, etc.) and plays Rs. 15,000 for it out of white money but gets a receipt of only Rs. 10,000, the balance of Rs. 5,000 becomes black money for the seller. In this case, the white money becomes the black money (Ahuja, 2007, 489).

The parallel economy has political, commercial, legal, industrial, social and ethical aspects. There are wide confrontations between the objectives of the legitimate and illegitimate sectors under parallel economy. D.R.Pendse (as cited by Lekhi, 2003, 191) argued that there are two possible sources of black money. Firstly, it may originate from illegitimate source of income arising out of illegal gratification such as payment of 'Selami or Pagri' or income from smuggling, bribery etc. Secondly, it may originate from legitimate and legal sources of income but concealed from tax authorities out of tax evasion.

The basic objectives of this paper are to analyze the causes of parallel economy, its impact on the economy and various initiatives of Indian government for solving this problem.

\section{INTERNATIONAL EXPERIENCE}

Parallel economy or black economy is existing in both developed and developing countries. There is an abundance of literature available upon measurement techniques and about estimates of parallel economy. A variety of methods have been used and the different methods appear to generate widely divergent estimates. This is summarized in Table 1. 
Table 1 : Parallel Economy Estimates in Developed Countries

\begin{tabular}{|c|c|}
\hline Country & $\begin{array}{c}\text { Parallel Economy (as \% of } \\
\text { GDP) }\end{array}$ \\
\hline Greece, Italy, Spain, Portugal and Belgium & $24-30 \%$ \\
\hline $\begin{array}{c}\text { Sweden, Norway, Denmark, Ireland, France, The } \\
\text { Netherlands, Germany and Great Britain }\end{array}$ & $13-23 \%$ \\
\hline Japan, USA, Austria and Switzerland & $8-10 \%$ \\
\hline
\end{tabular}

Source: http://www.crisil.com/youngthoughtleader/winners/topic4_Jyoti_Agarwal_IIm_CAL.PDF

Table 1 show that parallel economy exists in various developed countries all though their various initiatives have been taking governments.

The estimates of parallel economy in the context of some of the developing countries are presented in Table 2 .

Table 2: Estimates of Parallel Economy in Developing Countries Period: 1990-93

\begin{tabular}{|c|c|}
\hline Country & $\begin{array}{c}\text { Parallel Economy (as } \\
\% \text { of GDP) }\end{array}$ \\
\hline \multicolumn{2}{|l|}{ Africa } \\
\hline Nigeria and Egypt & $68-76 \%$ \\
\hline Tunisia and Morocco & $39-49 \%$ \\
\hline \multicolumn{2}{|l|}{ Central and South America } \\
\hline Guatemala, Mexico, Peru and Panama & $40-60 \%$ \\
\hline Chile, Costa Rica, Venezuela, Brazil, Paraguay \& Colombia & $25-35 \%$ \\
\hline \multicolumn{2}{|l|}{ Asia } \\
\hline Thailand & $70 \%$ \\
\hline Philippines, Sri-Lanka, Malaysia \& South Korea & $38-50 \%$ \\
\hline Hong Kong \& Singapore & $13 \%$ \\
\hline
\end{tabular}

Source: http://www.crisil.com/youngthoughtleader/winners/topic4_Jyoti_Agarwal_IIm_CAL.PDF

There are various developing countries where black money is increasing very quickly. It occurs at all levels of society, from local and national gove rnments, civil society, judiciary functions, large and small businesses, military and other services and so on.

\section{INDIAN EXPERIENCE}

Various attempts have been made to assess the black money in India from time to time. Major few of them are as presented here: 
I. Kaldor's Estimate: Although the Taxation Enquiry Commission had examined the structure of Indian Taxation, a review by Prof. Nicholas Kaldor was desired by the Government in late 1955 "in view of the larger dimensions assumed by the problems of resources for the plan since the commission reported (Important Events 1946-61)." Prof. N. Kaldor in his report on Indian Tax Reform estimated the non-national income (i) wages and salaries (ii) income of self-employed and (iii) profit, interest and rent. After making the rough adjustmements, according to Wanchoo Committee, "the estimated income income on which tax has been (black income) would probably be Rs. 700 crores and Rs. 1000 crores for the years 1961-62 and 1965-66 respectively. Projecting this estimate further to $1968-69$ on the basis of percentage increase in national income from 1961-62 to 1968-69, the income on which tax was evaded for 1968-69, the income on which tax was evaded for 1968-69 can be estimated at a figure of Rs. 1800 crores" (Datt and Sundharam, 2004, 378-379).

II. Wanchoo Committee's Estimate: Shri K.N.Wanchoo, retired Chief Justice of the Supreme Court of India, as chairman explained what the term black money meant in its final report submitted in December, 1971. This committee estimated non-salary income for 1961-62 of amounting Rs. 2686 crores and non-salary income actually assessed to tax as Rs. 1875 crores, thus, tax escaped for Rs. 811 crores. Therefore, in 1961-62, black money was of amounting Rs. 700 crores which rose to Rs. 1000 crores in 1965-66 and further Rs. 1400 crores in 1969-70. Very lately it was accounted to be 4.4 percent of GNP (Dhar, 2003, 719).

III. Rangnekar's Estimate: D.K. Rangnakar as a member of the Wanchoo Committee submitted his report in 1982 (India Today, 2005). According to Rangnekar, tax evaded income for 1961-62 was the order of Rs. 1,150 crores, as compared to the DTEC estimate of Rs. 850 crores. For 1965-66, it was Rs. 2,300 crores, as against Rs. 1,216 crores estimated by DTEC. The projections of black money for 1968-69 and 1969-70 were Rs. 2,833 crores and Rs. 3,080 crores respectively (Datt and Sundharam, 2004, 378).

IV. Chopra's Estimate: A Committee under O.P. Chopra was formed in 1982 for measuring black money in India (India Today, 2005). O.P.Chopra prepared a series of estimates of black income where it increased from Rs. 916 crores (6.1 percent of GDP) in 1961-62 to Rs.8098 crores (10.5 percent of GDP) in 1976-77 (Dhar, 2003). The study showed that a buoyant economy offers more opportunities for unaccounted income. During periods of recession, it may be difficult for producers to exact unaccounted money. Chopra also corroborates the hypothesis that tax evasion is more likely the higher the rate of tax. His findings also support the hypothesis that increase in prices leads to an increase in unaccounted income. Further, he found that funds are diverted to agriculture to convert unaccounted (black) income into legal (white) income (Datt and Sundharam, 2004, 379). 
V. Gupta's Estimate: Government of India formed a committee under Poonam Gupta and Sanjeev Gupta in 1981 for calculating black money in India. They used Feige's method of transaction income ratio to estimate black money in a country. They used average of three years viz. 1949-50, 1950-51 and 1951-52 as the bench mark for estimating black money for the year of 1967-68 to 1978-79. They estimated that it was $19.8 \%$ of GDP at market price. The black money increased for Rs. 3034 crores in 1967-68 to Rs. 46867 crores in 1978-79. The main findings of studies on black money were: (a) A buoyant economy offers more opportunities for unaccounted income; (b) The ratio of unaccounted income to assessable non-salary income has gone up after 1973-74; (c) Increase in prices leads to an increase in black money; (d) Funds are diverted to agriculture to convert black money into white money; and (e) One per cent increase in overall taxes leads to more than 3 percent increase in the black economy relation to the official economy (Lekhi, 2003, 192).

The National Institute of Public Finance and Policy estimated that in 1985 amount of black money in India was nearly Rs. 1,00,000 crore, which is approximately 20 percent of the national income. In 1996, the estimated black money was believed to be more than Rs. 4, 00,000 crore (The Hindustan Times, January 20, 1997).

Most of India's black money - estimated to be about US\$1 trillion (Dh3.67tn) - is believed to be parked in bank accounts in Switzerland. According to the Swiss Bankers Association, Swiss law and tax agreements prohibit third countries from general searches for possible tax evaders, or "name-fishing". The Indian government hopes that situation will change after its tax treaty with the country is revised (Chopra, 2010) .

\section{CAUSES OF GENERATING BLACK MONEY}

There are many reasons for the creation of back money in India. Some of them are as follows:

i. Controls and licensing system: Black money is increasing in India for the reasons of controls, permits, quotas and licenses.

ii. Higher Rates of Taxes: Higher rates of taxes has resulted a growing tendency of tax evasion among the tax payers. Tax evasion is common in income tax, corporate tax, corporation tax, union excise duties, custom duties, sales tax, etc.

iii. Ineffective enforcement of tax laws: In India, the enforcement of tax laws in respect of income tax, sales tax, excise duty, stamp duty etc. is quite weak. This has led to enormous unrestrained evasion of taxes and piling up of black money.

iv. Funding of political parties: There is an upward tendency of supporting of political parties with the help of black money. Big trade houses are donating 
an enormous amount of black money to the political parties, especially the ruling party with the sole objective to tame the political leadership for deriving undue profit by manipulating policy decisions (Lekhi, 2003, 193).

v. Second World War after influence: During the time of Second World War, a lot of the Indian industry found circumstances favourable for black marketing. Supply industrial goods from the traditional supplies of the West were cutoff, which resulted severe shortages in many essential fields. This formed the sentiment of making of marketing money out of shortages and not out of extension of the business activities.

vi. Inflation: The addition in prices of commodities like petrol, etc. in international market, boost in prices of commodities due to high increase in duties and taxes imposed by the government, the conspicuous utilization created by people with unaccountable money, diverting resources from manufacture to speculation- all these is the root of inflation which in turn creates black money.

vii. Agricultural Income: The reluctance to bring agricultural earnings in the realm of income tax has also contributed to creation of black money. Big industrial houses, over the past few decades have entered the agriculture sector in a big way by acquiring big farms. The black money accrued from other sources is sought to be transformed into white by viewing it on the agricultural returns account.

viii. Privatization: Privatization has opened up a new area to the private sector as well as to ministers and bureaucrats for making black money. It is expected that many scams come to light for making black money through privatization.

ix. Transactions in Urban Real Estates: Real estate transaction is a significant source of generating black money in India.

x. Other Factors: Generation of black income in a country like India also results from other different activities like smuggling, property deals, bribery, kickbacks, commissions, concealment of income by professionals, artists etc. In this way an enormous amounts of black income incessantly results in enhancement of the area and activities of parallel economy (Lekhi, 2003, 194).

\section{Impact of Black Income on the Indian Economy}

Generation of black income and thereby establishment of parallel economy has been creating the following serious impacts on the social and economic system of the country.

- Black income has been causing underestimation of GDP in India as an enormous volume of income is diverted to this unaccounted sector resulting in growing continuation of parallel economy of the country. 
- The direct effect of black income is the loss of revenue to the state exchequer as a tax evasion.

- Black money has resulted in the diversion of resources for the purchase of real estate and luxury housing.

- Black money has resulted in transfer of funds from India to foreign countries through clandestine channels (Dhar, 2003, 721).

- The availability of black incomes with businessmen and capitalists and the consequent inequalities of income place a large amount of funds at their disposal.

- A part of the black incomes is held in cash and as a result there is an abundance of liquidity which becomes available through the addition of savings held in the form of cash, bullion, gold, silver, etc.

- Money evaded by illegitimate way is spent in undesirable and vulgar manner. Virtues like hardwork and honesty are underestimated.

Thus the existence of parallel economy has totally distorted and disrupted the planning of the economy of the country.

\section{GOVERNMENT INITIATIVES}

The government has taken a number of steps to curb black money. Searches, seizures, surveys, and scrutiny of income tax returns are being done by the Income Tax Department. Amendments have also been made to the Finance Act 2004 to intensify efforts to curb black money. These include prosecution for falsification of books of accounts and taxing of gifts worth more than Rs. 25, 000 to unrelated persons. There have been two amendments of the Voluntary Disclosure of Income Scheme (VDIS) under which black incomes and assets could be declared, the tax paid at current rates and amnesty availed from penalty and prosecution. For the smooth functioning of the economy, the following measures are suggested to combat the menace of the parallel economy:

i. Demonetization: In 1946, demonetization was resorted to but the Direct Taxes Enquiry Committee in its interim report observed, "Demonetization was not successful then, because only a very small proportion of total notes in circulation were demonetized in 1946 and its worth was Rs.1,235.93 crores." On January 16, 1978 demonetization of high demonisation notes was introduced. The high demonetization rates as on that day amounted to Rs. 146 crores. Notes tendered to Reserve Bank of India amounted to Rs. 125 crores as per data available till August 1981 (Lekhi, 2003, 195).

ii. Voluntary Disclosure Schemes: The Government has floated various voluntary disclosure schemes to determine the black money. In 1951, a voluntary 
disclosure scheme with relaxation in panel provision was introduced. It resulted in total disclosures amounting to Rs. 71 crores and tax collection of Rs. 11 crores only. Up to 1968 a total concealed income of the order of Rs. 519 crores was declared on which Rs. 131 crores were paid as tax; this further highlights the failure of the Government to unearth black incomes. The wealth disclosed under the scheme will attract income tax, but not wealth tax. Under the scheme, previously undisclosed income reported by the declarant, will be subject to tax at the rate of $30 \%$ for individuals and 35\% in other cases. Further, the Finance Minister has announced that the declarant will not be liable to pay interest or penalties and will be granted immunity from prosecution under the Income tax Act 1961, Wealth tax Act, 1957, Foreign Exchange Regulation Act, 1973 and Companies Act, 1956. This scheme will remain in force till December 31, 1997 (Highlights of Union Budgets, 1997).

iii. Special Bearer Bond Scheme: Bearer bonds were most likely first used in the United States during the post-Civil War era to fund Reconstruction (18651885). Eare bonds that are owned by whoever is holding them, rather than having registered owners like most other securities. LikeEmost other bonds, they have a stated maturity date and interest rate, but coupons representing interest payments are generally physically attached to the security and must be submitted to the company for payment (Bernfeld, 2010). Special Bearer Bonds Scheme (1981) was intended for canalizing unaccounted money for productive purposes. The Special Bearer Bonds, 1981 of the face value of Rs. 10,000 each were issued at par with a maturity period of 10 years.

iv. Measures to Check Tax Evasion: Dealing with tax evasion has always been one of the most difficult challenges for governments all round the world. Tax evasion is done by individuals belonging to different strata of the society in different ways. As per the surveys and reports, there are many people who provide false income details to the tax authorities to reduce the amount of liability. The income tax evasion penalties can help the government recover maximum amounts in the form of tax and utilize the money for the benefit of the common public. Tax evasion is one of the basic causes to generate the black income. Therefore, various measures were undertaken to plug the loopholes in tax evasion. Most of these measures were based on the recommendations of various committees and commissions viz Taxation Enquiry Commission (1953), Administrative Reforms Commission (1969), Direct Tax Enquiry Committee (1971) etc. Most of these recommendations were an upgrading in tax laws (Charlie, 2010).

v. Economic Liberalization: Introduction of economic liberalization has detached the regime of controls and regulations and thereby the extent of black economy would be reduced regularly (Lekhi, 2003, 196).

vi. Voluntary Disclosure Scheme: Finance Minister Mr. P. Chidambaram while presenting 1997-98 budgets announced a Voluntary Disclosure Scheme (VDS). 
Voluntary Disclosure Scheme which was extensively advertised yielded tax revenue of Rs.10, 500 crores- an unprecedented revenue gain from any VDS scheme launched since the independence.

vii. Other Measures: The Government has also introduced some measures to contain the growth of black income in the country which includes Deposit in the National Housing Bank in 1991, NRI foreign exchange remittance, issuing National Development Bonds in US dollars, controlling the election expenses incurred by the candidates, conducting searches, seizures, raids and other steps to plug loopholes in the tax administration etc.

The Prevention of Money-Laundering Act, 2004 came into effect on 1 July 2005. Section 3 of the Act makes the offense of money-laundering cover those persons or entities who directly or indirectly attempt to indulge or knowingly assist or knowingly are party or are actually involved in any process or activity connected with the proceeds of crime and projecting it as untainted property, such person or entity shall be guilty of offense of money-laundering. Section 4 of the Act prescribes punishment for moneylaundering with rigorous imprisonment for a term which shall not be less than three years but which may extend to seven years and shall also be liable to fine which may extend to five lakh rupees and for the offences mentioned [elsewhere] the punishment shall be up to ten years (Money Laundering, 2010). Money laundering networks have and continue to provide avenues to siphon money between individuals, groups, and nations across national borders and across the world for legitimate and illegitimate purposes (Lambert, 1996).

In July 1991, the Union Finance Minister projected a new scheme- National Housing Bank Scheme to persuade black money back into the legitimate operations of the national economy. The scheme offered possessors of unaccounted for money an opportunity to deposit any quantity of money (with a maximum limit of Rs. 10000) with NHB without disclosing the basis of funds.

Some scholars have maintained that all these measures have touched only the tip of the iceberg. All of schemes have hardly fetched Rs. 5000 crore over a period of fifty years. The main drawback in these schemes is that they touch the problem of black money already created but they do not go into the root cause of generation of black money. Unless this problem is tackled, the menace of black money will continue to increase.

India has tried to combat tax evasion by requiring an identification number for all major financial deals. The permanent account number (PAN) is a compulsory 10-character number issued to taxpayers by the tax department. But many transactions, especially those related to property, are conducted in cash and are unlikely to be reported. In the fiscal year 2007-2008, the country's high-value transactions amounted to more 
than 55.7 trillion rupees, according to India's Annual Information Return filed with the government. But nearly one third of the 3.3 million transactions were conducted without a PAN. In many other transactions, PAN numbers were fake (Chopra, 2010).

\section{CONCLUDING OBSERVATION}

Parallel economy is a new threat for the Indian economy. In India parallel economy is expanding very rapidly. Government of India introduced commissions under Kaldor, Wanchoo, Rangnekar, Chopra, and Gupta for estimating black economy. There are many factors like Controls and Licensing System, Higher Rates of Taxes, Ineffective Enforcement of Tax Laws, Inflation, Funding of political parties etc. that influence its growth.

In India amount of black money are increasing continuously which badly impacts the economic growth of the nation. Such money is a new challenge for Indian economy. Indian economy is badly affected by black money as it is underestimating GDP, increasing inequality of income, increasing illegal activities etc. Over the past 50 years, the government has at various times announced several schemes offering opportunities to bring black money overboard but the result are not so effective. Some of these schemes are: introducing the scheme of Special Bearer Bonds, demonetizing high denomination currency notes, stringent raids and scheme of voluntary disclosures. These instruments are expected to reduce the volume of the black economy.

\section{References}

Ahuja, R. (2007). Social Problems in India (2 ${ }^{\text {nd }}$ Ed). Jaipur: Rawat Publications.

Bernfeld, G. (2010). Bearer Bonds: From Popular to Prohibited. Retrieved from http://www. investopedia.com/articles/bonds/08/bearer-bond.asp\#12913328237032\&close

Black Economic Empowerment (2010, November 12). Retrieved from http://en.wikipedia.org/wiki/ Black_Economic_Empowerment

Black money is a curse of our nation (2010). Retrieved from http://www.slideshare.net/sridharababu/ black-money-is-a-curse-to-our-nation

Charlie, S. (2010). Tax Evasions Penalties. Retrieved from http://www.buzzle.com/articles/taxevasion-penalties.html

Chopra, A. (2010). India targets black money. Retrieved from http://www.thenational.ae/business/ economy/india-targets-black-money

Datta, R., \& Sundharam, K. (2004). Indian Economy (49 $9^{\text {th }}$ Ed). New Delhi: S. Chand \& Company Ltd. 376 \& 378-379.

Dhar, P. K. (2003). Indian Economy: Its Growing Dimensions (11 ${ }^{\text {th }}$ Ed). Ludhiana: Kalyani Publishers.

Highlights of Union Budgets. (1997). Retrieved from http://iic.nic.in/iic4_g.htm 
Important Events 1946-61 (2010). Retrieved from http://www.incometaxindia.gov.in/ HISTORY/1946-1961.ASP

India Today (2005, December 19). Cover Story: Black Money. Retrieved from http://www.indiatoday.com/itoday/20051219/cover2.html

Lambert, L. (1996). Underground Banking and National Security. Retrieved from http://www. subcontinent.com/sapra/bulletin/96feb-mar/si960308.html

Lekhi, R. (2003). The Economics of Development and Planning ( $8^{\text {th }}$ Ed). Ludhina: Kalyani Publications.

Money Laundering. (2010, November 30). Retrieved from http://en.wikipedia.org/wiki/Money_ laundering

Rajaram, K. (2006). Indian Economics (6 $6^{\text {th }}$ ed.). New Delhi: Spectrum Books Pvt. Ltd. 